\title{
Herbal Extracts Modulate the Amplitude and Frequency of Slow Waves in Circular Smooth Muscle of Mouse Small Intestine
}

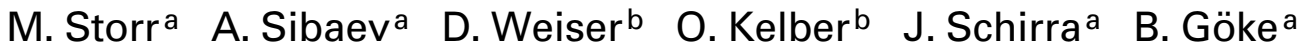 \\ H.D. Allescherc
}

a Department of Internal Medicine II and Institute for Surgical Research, Ludwig Maximilian University of Munich, bSteigerwald Arzneimittelwerk, Darmstadt, "Klinikum Garmisch-Partenkirchen, Garmisch-Partenkirchen, Germany

\section{Key Words}

Herbal extracts - STW 5 - Intestinal slow waves •

Electrophysiology

\begin{abstract}
Background: Herbal preparations like STW 5 (Iberogast ${ }^{\circledR}$ ) are widely used drugs in the treatment of dyspepsia and motility-related disorders of the gastrointestinal tract. STW 5 is a phytotherapeutic agent consisting of a fixed mixture of 9 individual plant extracts. The electrophysiological mechanisms of action of STW 5 remain obscure. Aim: The aim of the present study was to investigate whether herbal extracts influence electrophysiological parameters of the small intestine. For this purpose, the resting membrane potential (RMP) and the slow wave rhythmicity of smooth muscle cells of mouse small intestine were observed. Methods: Intracellular recordings of smooth muscle cells of the circular muscle layer of mouse small intestine were performed using standard microelectrode techniques. After dissection of the mucosa, the small intestine was placed in an organ bath and a microelectrode was applied on a circular smooth muscle cell. The RMP and the amplitude of slow waves were measured in millivolts. Results: The RMP of smooth muscle cells was $-59 \pm 1.3 \mathrm{mV}$. This RMP was signifi-
\end{abstract}

cantly depolarized by STW $5(9.6 \pm 1.6 \mathrm{mV})$; the depolarizing effects can be mainly attributed to the constituents of matricariae flos, angelicae radix and chelidonii herba. The basal frequency of small intestinal slow waves was $39.5 \pm 1.4 \mathrm{~min}^{-1}$ and the amplitude was $23.1 \pm 0.9 \mathrm{mV}$. STW 5 significantly reduced the amplitude and frequency of the slow waves $\left(11.7 \pm 0.8 \mathrm{mV} ; 33.5 \pm 3.4 \mathrm{~min}^{-1}\right)$. This effect on slow waves represents the sum of the effects of the 9 phytoextracts. Whereas angelicae radix and matricariae flos completely blocked slow wave activity, Iberis amara increased the frequency and amplitude, chelidonii herba reduced the frequency and amplitude of the slow waves, mentae piperitae folium reduced the frequency and left amplitude unchanged and liquiritae radix, carvi fructus and melissae folium had no effects. Conclusion: Herbal extracts cause changes in smooth muscle RMP and slow wave rhythmicity, up to reversible abolition, by blockade of large conductance $\mathrm{Ca}^{2+}$ channels and other not yet identified mechanisms. In herbal preparations like STW 5 these effects add up to a total effect and this study indicates that herbal preparations which are widely used in dyspepsia and motility-related disorders have characteristic, reproducible, reversible effects on small intestinal electrophysiology.

Copyright $@ 2005$ S. Karger AG, Basel

\begin{tabular}{ll}
\hline KARGER & ( ) 2004 S. Karger AG, Basel \\
Fax +4161306 1234 $34282 / 04 / 0704-0257 \$ 21.00 / 0$ \\
$\begin{array}{l}\text { E-Mail karger@karger.ch } \\
\text { www.karger.com }\end{array}$ & $\begin{array}{l}\text { Accessible online at: } \\
\text { www.karger.com/dig }\end{array}$
\end{tabular}

Dr. Martin Storr

II. Med. Klinik und Poliklinik der Ludwig-Maximilians-Universität München

Marchioninistrasse 15

DE-81377 Munich (Germany)

Tel. +41 897095 2281, Fax +41 897095 5281, E-Mail martin.storr@med.uni-muenchen.de 


\section{Introduction}

Functional gastrointestinal disorders like functional dyspepsia and motility-associated disorders like irritable bowel syndrome (IBS) are often treated symptomatically employing herbal extracts. Among these STW 5 is widely used in Europe [1-5].

STW 5 is a fixed combination of ethanolic extracts of 9 different herbal constituents with a final ethanol concentration of $31 \%$. The 9 individual herbal extracts are from Iberis amara (15\%), angelicae radix (10\%), carvi fructus $(10 \%)$, cardui mariae fructus $(10 \%)$, chelidonii herba $(10 \%)$, liquiritae radix (10\%), matricariae flos $(20 \%)$, melissa folium (10\%) and menthae piperitae folium (5\%) [6].

The pathophysiological concepts of functional disorders of the intestine notably include motility disturbances and/or acid production as underlying mechanisms. Hypersensitivity of the gut and the autonomic nervous system were suggested as possible additional mechanisms underlying some of the functional disorders. This means that minimal disturbances of physiological processes may cause exaggerated sensations within the gastrointestinal tract.

Small intestine motility is regulated by a number of circuits including the peristaltic reflex, migrating motor complexes and slow wave rhythmicity generated by the interstitial cells of Cajal (ICC). Among these, slow waves generated by the ICC are the electrophysiological basis of peristaltic smooth muscle contractions [7, 8]. Smooth muscle spikes initiated in response to slow waves appear to propagate through the smooth muscle layer and are often the first step in the excitation coupling mechanism leading to contraction [9-12]. The smooth muscle cell itself appears to act chiefly as recipient of the slow wave, which it transforms into patterns of contraction $[13,14]$. The coupling of ICC and smooth muscle cells is strongly believed to occur via gap junctions. Morphological evidence for this motion has been provided by electron microscopy but due to the lack of highly selective gap junction blockers, final functional evidence is still missing [15-18]. Though membrane potentials and slow waves can be modulated by the known excitatory and inhibitory neurotransmitters, none of the established neurotransmitters can reversibly abolish slow wave activity $[9,19,20]$.

To date little if anything is known on the possible effects of herbal extracts or herbal preparations like STW 5 on intestinal motility and intestinal electrophysiology, though they have been used for decades with symptomatic benefit in patients with functional dyspepsia and IBS.
Therefore the aim of this investigation was to evaluate the possible effects of different herbal preparations on the small intestine by recording membrane potentials of circular smooth muscle cells and describe changes in resting membrane potentials (RMP) and intestinal slow wave rhythmicity.

\section{Materials and Methods}

Tissue Preparation for Electrophysiological Experiments

Eight- to ten-week-old male mice BALB/C were anesthetized with sodium pentobarbital and sacrificed by cervical dislocation in accordance with the recommendations of the government of the state of Bavaria, Germany. The complete small bowel was removed and placed into oxygenated Krebs solution of the following composition $(\mathrm{m} M): \mathrm{NaCl} 120.35 ; \mathrm{KCl}$ 5.9; $\mathrm{MgCl}_{2}, 2.5 ; \mathrm{NaH}_{2} \mathrm{PO}_{4} 1.2 ; \mathrm{NaHCO}_{3}$ $15.5 ; \mathrm{CaCl}_{2} 2.5$; glucose 11.5, $\mathrm{pH}$ 7.4. The small intestine was opened along the mesenteric border, cleaned of remaining fecal matter and pinned out in a Sylgard-lined (Dow Corning Corp.; Midland, Mich., USA) dissecting dish containing oxygenated Krebs solution. The proximal small intestine was separated and the mucosa and submucosa were removed, resulting in sheets of tissue consisting of circular and longitudinal muscle layers, together with the attached myenteric plexus.

\section{Intracellular Electrical Recording}

Intracellular electrical recordings were performed as described recently for mouse colon [21,22]. Sheets of muscle were pinned to the Sylgard-based electrophysiological chamber using approximately 150-200 micropins (15-25 $\mu \mathrm{m}$ in thickness) made of wolfram wire; the circular muscle layer was uppermost. The chamber was perfused ( $5 \mathrm{ml} / \mathrm{min}^{-1}$; Kwik Pump, World Precision Instruments; Sarasota, Fla., USA) with prewarmed $\left(37^{\circ} \mathrm{C}\right)$ oxygenated $\left(95 \% \mathrm{O}_{2}-5 \% \mathrm{CO}_{2}\right)$ Krebs solution. Tissues were allowed to equilibrate for 90-120 min before the experiments were started. Nifedipine $(1 \mu M)$ was present throughout all experiments unless otherwise stated. Capillary glass microelectrodes (borosilicate glass capillaries, $1.0 \mathrm{~mm}$ outer diameter $\times 0.58 \mathrm{~mm}$ inner diameter, Clark Electromedical Instruments; Edenbridge, UK) were made using a microelectrode puller (Model P-97, 3 mm wide filament, Sutter Instruments; Novato, Calif., USA), filled with $\mathrm{KCl}(3 M)$ and had resistances in the range of 80 $120 \mathrm{M} \Omega$. After the equilibration period, a circular smooth muscle cell was impaled and the membrane potential was recorded against a 'ground' $\mathrm{Ag}-\mathrm{AgCl}$ electrode placed in the bath medium. Then the tested drugs were added in the perfusate of the organ bath in increasing concentrations. Electrical events were amplified (DUO 733 microelectrode amplifier, World Precision Instruments; Sarasota, Fla., USA) and digitalized with an analogue-to-digital converter (SCB 68 interface, National Instruments; Austin, Tex., USA). Permanent recordings of membrane potentials were made on a personal computer running the LABVIEW 5.0 program (National Instruments; Austin, Tex., USA).

Data Presentation and Statistical Analysis

RMPs (mV) and slow wave activity (frequency/amplitude) were recorded. The amplitudes were measured in millivolts as compared to the RMP. 
All data are given as mean \pm standard error of the mean; $n$ indicates the number of independent observations in intracellular recordings from different animals. Statistical differences between the treatment groups were tested using a commercial statistical package (SigmaStat, Jandel Scientific; San Rafael, Calif., USA) using the paired or unpaired Student $t$ test as appropriate, followed by Bonferroni post hoc testing. A probability of less than $5 \%$ that the null hypothesis is false was considered to be significant.

\section{Drugs}

The drugs used were: nifedipine, tetrodotoxin (TTX), guanethidine, atropine, hexamethonium, ethanol (all: Sigma-Aldrich; Taufkirchen, Germany); herbal preparations: STW 5 (Iberogast ${ }^{\circledR}$ ), STW 7 (STW 5 without Iberis amara); herbal extracts: I. amara, angelicae radix, carvi fructus, cardui mariae fructus, chelidonii herba, liquiritae radix, matricariae flos, melissae folium, mentae piperitae folium (all: Steigerwald Arzneimittelwerk GmbH, Darmstadt, Germany). The herbal extracts were either used as lyophilized extracts or dissolved in ethanol, as indicated in the Methods and Results sections. The individual solutions were used at the same concentrations as in STW 5.

The drugs were freshly dissolved in saline on the day of the experiment and further diluted in Krebs solution to organ bath concentrations. Drugs were added to the perfusate, and experiments were controlled for the effects of the drug solvents (ethanol).

\section{Results}

\section{Recording of Circular Smooth Muscle Membrane \\ Potential and Slow Wave Rhythmicity}

In the absence of drugs, circular smooth muscle cells of the small intestine displayed a stable RMP $-59 \pm 1.3 \mathrm{mV}$ and a stable slow wave activity with an amplitude of 23.1 $\pm 0.9 \mathrm{mV}$ and a frequency of $39.5 \pm 1.4 \mathrm{~min}^{-1}(\mathrm{n}=15)$. Additionally, an irregular spiking activity could be seen following slow wave rhythmicity. Nifedipine $(10 \mu M)$, which blocks large conductance $\mathrm{Ca}^{2+}$ channels did not significantly alter RMP or slow wave activity, whereas spiking activity following slow wave depolarization was abolished. Neither the neuronal blocker TTX $(3 \mu M)$ nor atropine $(1 \mu M)$ or guanethidine $(1 \mu M)$ had an influence on RMP, slow wave rhythmicity or amplitude and spiking activity (data not shown).

\section{Influence of STW 5 on RMP and Slow Wave Activity}

STW 5 used as ethanolic solution dose-dependently depolarized RMP [1:1,000: +1.5 $\pm 1.2 \mathrm{mV} ; 1: 100:+3.6$ $\pm 0.7 \mathrm{mV} ; 1: 50:+6.8 \pm 0.6 \mathrm{mV}(\mathrm{p}<0.05) ; 1: 10:+17.0 \pm$ $0.4 \mathrm{mV}(\mathrm{p}<0.05) ; \mathrm{n}=7]$ and reduced slow wave frequency [control: $39.5 \pm 1.4 \mathrm{~min}^{-1}$; 1:1,000: $43.0 \pm 1.0 \mathrm{~min}^{-1}$; 1:100: $37.8 \pm 0.9 \mathrm{~min}^{-1} ; 1: 50: 22.9 \pm 1.5 \mathrm{~min}^{-1}(\mathrm{p}<0.05$ and $\mathrm{p}<0.05$ vs. ethanol effect $) ; 1: 10$ : abolished; $\mathrm{n}=7(\mathrm{p}<$ 0.05 and $\mathrm{p}<0.05$ vs. ethanol effect)] and slow wave

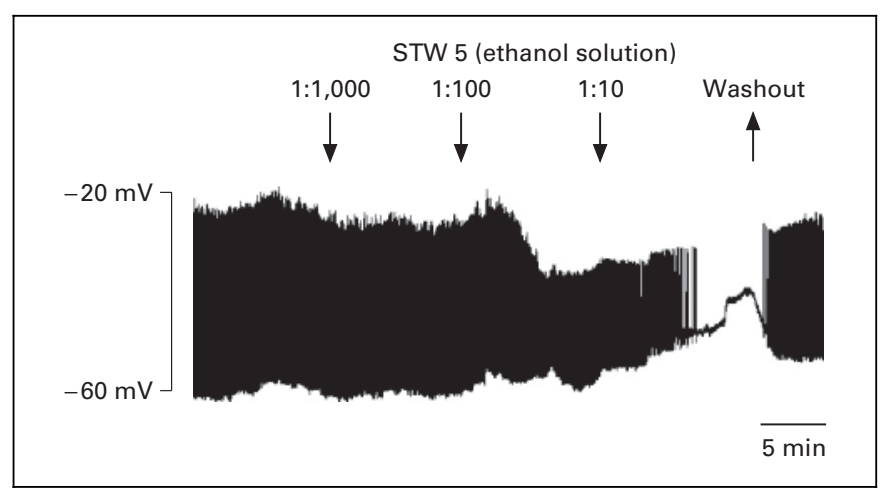

Fig. 1. The figure shows an original recording of circular smooth muscle cell RMP, slow wave activity and spiking activity. STW 5 (ethanolic solution) was added in the chamber perfusate stepwise every $10 \mathrm{~min}$. Please note the depolarizing effect on RMP and the depressant effect on slow wave activity until abolition, which is reversible after removal of STW 5 from the organ bath.

amplitude [(control: $23.1 \pm 0.9 \mathrm{mV}) ; 1: 1,000: 27.1 \pm$ $1.0 \mathrm{mV}$; 1:100: $18.5 \pm 3.0 \mathrm{mV}(\mathrm{p}<0.05) ; 1: 50: 6.3 \pm$ $1.5 \mathrm{mV}(\mathrm{p}<0.05$ and $\mathrm{p}<0.05$ vs. ethanol effect); $1: 10$ : abolished; $\mathrm{n}=7,(\mathrm{p}<0.05 ; \mathrm{p}<0.05$ vs. ethanol effect $)]$ up to abolition (fig. 1). The abolition was immediately reversible when STW 5 was removed from the organ bath (fig. 1). The spiking activity following slow waves was abolished at concentrations higher than 1:100 (fig. 1,2).

STW 5 used as solution from lyophilized extracts dosedependently depolarized RMP [1:1,000: $+4.5 \pm 1.2 \mathrm{mV}$; 1:100: +6.6 $\pm 1.8 \mathrm{mV} ; 1: 50:+9.6 \pm 1.6 \mathrm{mV}(\mathrm{p}<0.05)$; $\mathrm{n}=6]$ and reduced slow wave frequency [1:1,000: $46.0 \pm$ $2.4 \mathrm{~min}^{-1}$; 1:100: $38.8 \pm 1.9 \mathrm{~min}^{-1} ; 1: 50: 33.5 \pm$ $\left.3.4 \min ^{-1}(\mathrm{p}<0.05) ; \mathrm{n}=6\right]$ and slow wave amplitude [1:1,000: $23.5 \pm 0.5 \mathrm{mV} ; 1: 100: 18.5 \pm 0.5 \mathrm{mV}(\mathrm{p}<$ 0.05); 1:50: $11.7 \pm 0.8 \mathrm{mV} ; \mathrm{n}=6$ ] up to abolition (fig. 3). The abolition was reversible when STW 5 was removed from the organ bath perfusate. The spiking activity following slow waves was abolished at concentrations higher than 1:100 (fig. 3).

Influence of Ethanol on RMP and Slow Wave Activity

Ethanol dose-dependently depolarized RMP [1:100: no change; $1: 50:+4.0 \pm 0.4 \mathrm{mV} ; 1: 10:+12.5 \pm 0.6 \mathrm{mV}$ $(\mathrm{p}<0.05) ; \mathrm{n}=6]$ and reduced slow wave frequency [1:100: $46.1 \pm 2.9$ min $^{-1}$; 1:50: $36.8 \pm 1.9$ min $^{-1}$; 1:10: $32.6 \pm$ $\left.1.7 \mathrm{~min}^{-1}(\mathrm{p}<0.05) ; \mathrm{n}=6\right]$, and slow wave amplitude [1:100: no change; $1: 50: 16.5 \pm 2.2 \mathrm{mV} ; 1: 10: 19.2 \pm$ $2.8 \mathrm{mV}(\mathrm{p}<0.05) ; \mathrm{n}=6]$. The effect was immediately reversible, when ethanol was removed from the organ 


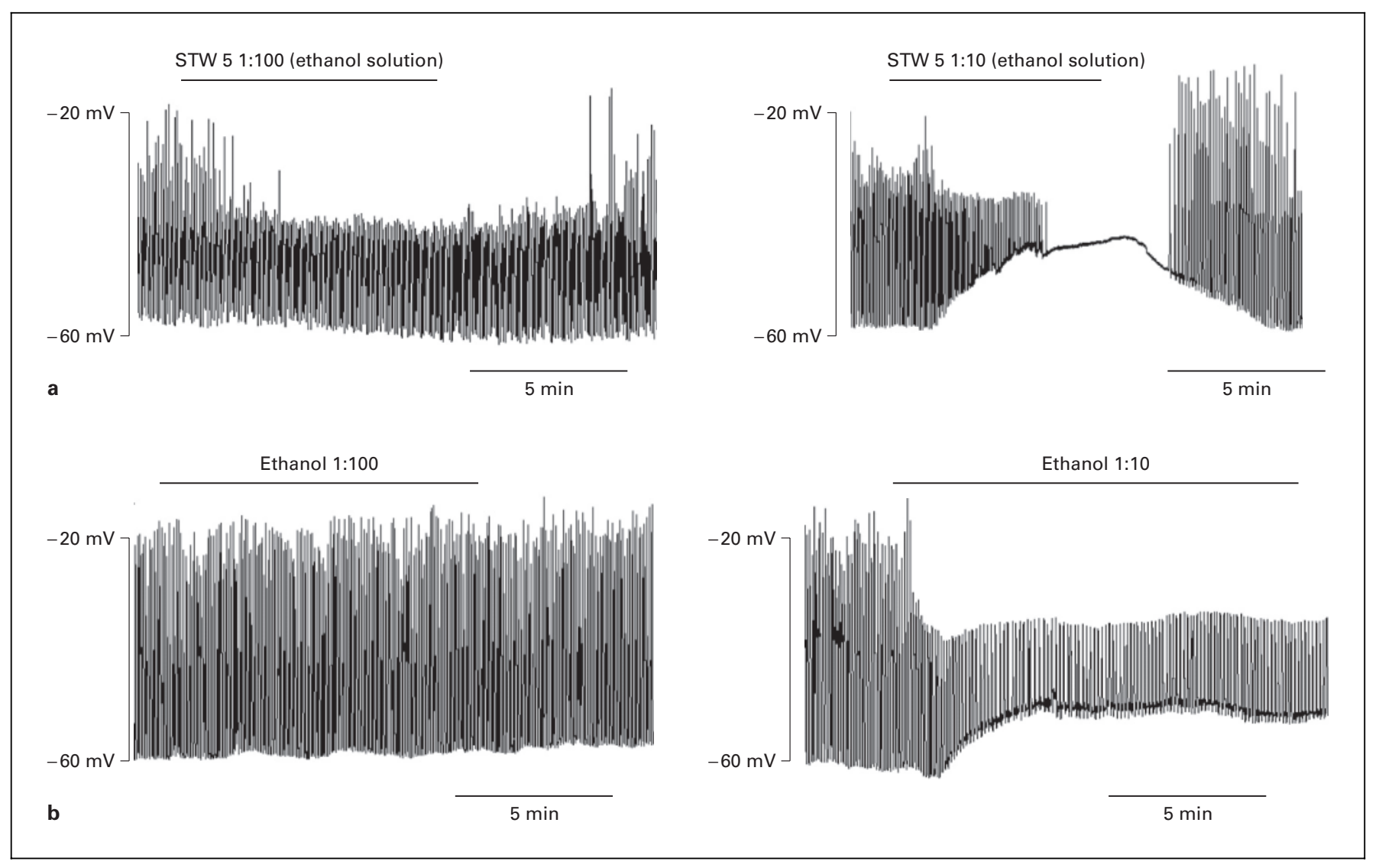

Fig. 2. a Depressant effect of STW 5 on spiking activity in response to slow waves for the 1:100 concentration and the depressant effect on slow wave activity up to abolition for the 1:10 concentration of STW 5. b Recordings of the same patterns in the presence of the same concentrations of ethanol solution as in the STW 5 solution. Please note that equal ethanol concentrations do not change the spiking activity at 1:100 whereas at 1:10 ethanol does influence RMP and slow wave activity, but the effects are far less marked than those observed for STW 5.

bath. However, the effects of ethanol were significantly lower than those of the ethanol-diluted herbal extract STW 5.

\section{Influence of STW 7 on RMP and Slow Wave Activity}

STW 7 used as ethanolic solution dose-dependently depolarized RMP [1:1,000: $+7.5 \pm 1.9 \mathrm{mV} ; 1: 100:+10.6$ $\pm 2.8 \mathrm{mV}(\mathrm{p}<0.05$ and $\mathrm{p}<0.05$ vs. ethanol effect $) ; 1: 50$ : $+16.8 \pm 3.6 \mathrm{mV}(\mathrm{p}<0.05$ and $\mathrm{p}<0.05$ vs. ethanol effect $)$; $\mathrm{n}=6]$ and reduced slow wave frequency [1:1,000: $47.0 \pm$ $2.6 \mathrm{~min}^{-1}$; 1:100: $36.8 \pm 1.9 \mathrm{~min}^{-1} ; 1: 50: 25.9 \pm$ $2.7 \mathrm{~min}^{-1}(\mathrm{p}<0.05$ and $\mathrm{p}<0.05$ vs. ethanol effect $\left.) ; \mathrm{n}=6\right]$ and slow wave amplitude [1:1,000:29.5 $\pm 0.8 \mathrm{mV} ; 1: 100$ : $17.5 \pm 1.2 \mathrm{mV}(\mathrm{p}<0.05$ and $\mathrm{p}<0.05$ vs. ethanol effect $)$; 1:50: $7.2 \pm 1.8 \mathrm{mV}(\mathrm{p}<0.05$ and $\mathrm{p}<0.05$ vs. ethanol

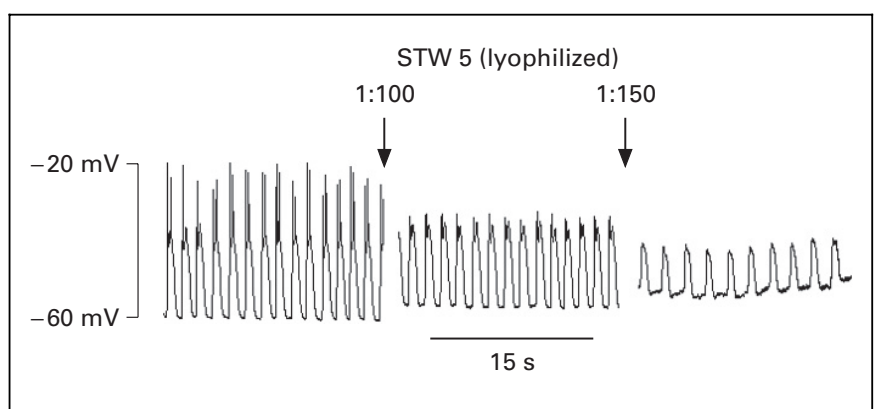

Fig. 3. Depressant effect of STW 5 used as lyophilized extract on smooth muscular spiking activity at the concentraction of 1:100 and depressant effect on slow wave amplitude and frequency at the concentration of 1:50. 


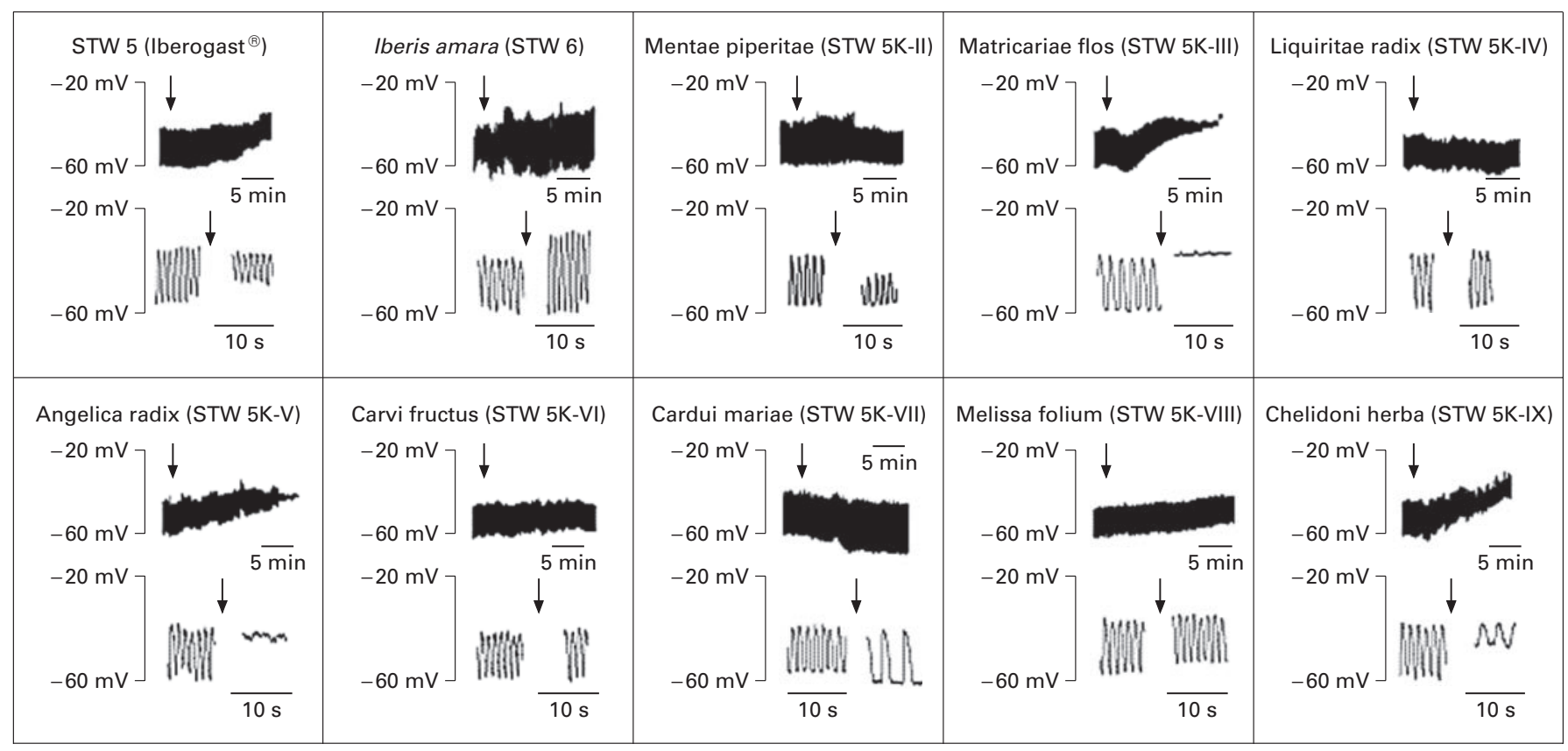

Fig. 4. Changes in slow wave activity and resting membrane potential for STW 5 and each individual herbal extract. Lyophilized herbal extracts at the concentration of 1:50.

Table 1. Effects of the herbal preparation STW 5 and the individual herbal extracts on RMP slow wave frequency and amplitude

\begin{tabular}{|c|c|c|c|}
\hline & $\begin{array}{l}\mathrm{RMP} \\
\mathrm{mV}\end{array}$ & $\begin{array}{l}\text { Amplitude } \\
\mathrm{mV}\end{array}$ & $\begin{array}{l}\text { Frequency } \\
\mathrm{min}^{-1}\end{array}$ \\
\hline Control & $-59 \pm 1.3$ & $23.1 \pm 0.9$ & $39.5 \pm 1.4$ \\
\hline STW 5 & $+9.6 \pm 1.6^{*}$ & $11.7 \pm 0.8^{*}$ & $33.5 \pm 3.4^{*}$ \\
\hline I. $\operatorname{amara}(\mathrm{STW} 6)$ & no change & $30.8 \pm 2.1^{*}$ & $50.2 \pm 2.9^{*}$ \\
\hline Mentae piperitae folium (STW 5K-II) & no change & $15.8 \pm 1.8^{*}$ & $\mathrm{NC}$ \\
\hline Matricariae flos (STW 5K-III) & $+19.3 \pm 1.9^{*}$ & abolished & abolished \\
\hline Liquiritae radix (STW 5-IV) & no change & no change & no change \\
\hline Angelicae radix (STW 5K-V) & $+12.5 \pm 1.8^{*}$ & abolished & abolished \\
\hline Carvi fructus (STW 5K-VI) & no change & no change & no change \\
\hline Cardui mariae fructus (STW 5K-VII) & $-5.0 \pm 0.9$ & $25.8 \pm 1.2$ & $13.3 \pm 2.3^{*}$ \\
\hline Melissae folium (STW 5K-VIII) & $+5.1 \pm 1.6$ & $20.2 \pm 1.5$ & $40.3 \pm 2.0$ \\
\hline Chelidonii herba (STW 5K-IX) & $+12.2 \pm 2.0^{*}$ & $11.8 \pm 1.7 *$ & $18.7 \pm 1.9^{*}$ \\
\hline
\end{tabular}

The herbal extracts used were ethanol-free lyophilized extracts diluted in KRS to the final bath concentration of 1:50. $* \mathrm{p}<0.05$ vs. untreated control. effect); $\mathrm{n}=6]$. The effect was immediately reversible, when STW 7 was removed from the organ bath.

\section{Influence of the Individual Herbal Extracts on RMP and Slow Wave Activity}

The individual herbal extracts used at the same concentration as in the herbal preparation STW 5 are still mixtures of various substances. They all had individual or no effects on RMP, slow wave activity and slow wave amplitude (fig. 4). The values of the effects of the individual lyophilized (ethanol free) herbal extracts added 1:50 into the organ bath are given in table 1 . 


\section{Discussion}

Treatment of functional dyspepsia and IBS is hampered by the lack of an accepted pathophysiological etiology. Presently various drugs influencing motility (e.g. spasmolytics, dopaminergics and serotoninergics) or hypersensitivity (e.g. antidepressants and serotoninergics) as well as herbal extracts are used. They all alleviate the patients' symptoms. Though clinical studies show that herbal extracts like STW 5 are potent antidyspeptic agents [1-5], little is known on their potential underlying mechanisms, notably on a possible regulation of gastrointestinal electrophysiological parameters.

Our data clearly show that STW 5 dose-dependently depolarized RMP of small intestinal smooth muscle cells. No individual herbal extract caused hyperpolarization, whereas various individual extracts caused depolarization. This depolarization influences smooth muscle excitability and since the effects of the extracts are reversible, these effects are suggested to be nontoxic.

The effects of the herbal extracts on slow wave amplitude and rhythmicity are more interesting. The slow waves are known to be generated by the ICC, and maximum slow wave frequency in turn sets the maximum frequency of contractions and determines the propagation characteristics of the rhythmic contractions in the intestine $[8,9,23,24]$ and no individual nontoxic drug can reversibly abolish slow wave rhythmicity. Abolition of slow waves is reported only in genetically modified mice missing the ICC [25]. Whereas the regulatory mechanisms responsible for slow wave generation are still unknown, frequency seems to be dependent on extracellular $\mathrm{Ca}^{2+}$ content as demonstrated by voltage clamp experiments [26] and on release of intracellularly stored $\mathrm{Ca}^{2+}$ [27]. Intestinal slow wave activity can be increased by drugs sensitizing $\mathrm{IP}_{3}$ receptors (inositol 1,4,5,-trisphosphate) involved in the regulation of $\mathrm{Ca}^{2+}$ release from the intracellular stores [28]. Electrical coupling of ICC to smooth muscle cells is believed to occur via a gap junctional coupling. Due to the absence of specific drugs modulating the gap junctional functioning, the interpretation of mechanisms modulating slow wave activity remains speculative. To our knowledge, this is the first report on drugs that reversibly abolish slow wave activity.

STW 5 potently reduced slow wave amplitude and frequency. This effect is clearly different from the effect of ethanol in equimolar concentrations. The reduction in slow waves in our study was also present when STW 5 was used in an ethanol-free lyophilized application form. As for the RMP, the different individual herbal extracts had different effects on the slow waves, ranging from an increase in amplitude and frequency for I. amara to a decrease in amplitude and frequency for other extracts. Some of the herbal extracts, notably liquiritae radix and carvi fructus extracts caused no significant effect on slow wave rhythmicity. This multiple mode of action when combined in the final herbal preparation resulted in a net depressant effect on slow waves. Though STW 5 and most of the single extracts caused depressant effects on slow waves, the I. amara extract augmented the slow waves, again pointing to a multiple mode of action of the herbal preparation STW 5 due to the combination of different herbal extracts. This multiple mode of action might be a reason why STW 5 exerts a beneficial effect on symptoms in functional disorders where more than one pathomechanism might come into play. The multiple mode of action is further stressed by the finding that STW 5 at low concentrations shows a trend towards increasing slow wave frequency and amplitude; thereafter, slow waves are depressed at higher concentrations.

We also investigated STW 7, which does not include I. amara extract, but whose composition is otherwise the same, in order to find out whether the removal of this extract, which augments the amplitude and frequency of slow waves, influences the global effects of the herbal preparation. Though we found a trend towards different effects of STW 5 and STW 7 in the lower concentrations, this difference did not reach statistical significance.

In addition to the reported effects on slow wave rhythmicity, STW 5 also abolished the spiking activity of smooth muscle cells in response to slow wave rhythmicity. This spiking activity following slow wave activity is the known first step in the excitation coupling mechanism leading to contraction of smooth muscle $[13,14]$. In agreement with others, the spiking activity in our experiments could be abolished by nifedipine, demonstrating its dependence on $\mathrm{Ca}^{2+}$ channel function. Since STW 5 abolishes this spiking activity, it may be suggested that smooth muscle contractility is reduced by mechanisms influencing slow waves and mechanisms regulating smooth muscle excitability. Which individual component of STW 5 influences muscular excitability, most likely by blockade of large conductance $\mathrm{Ca}^{2+}$ channels, will have to be answered by future investigations.

Besides the effects on motility parameters reported here, extracts of chelidonii herba and matricariae flos show high affinity binding on $5-\mathrm{HT}_{4}$ receptors, but functional data on the effects on gastrointestinal motility are still missing [29]. The binding on 5- $\mathrm{HT}_{4}$ receptors gives further evidence on possible mechanisms influencing gas- 
trointestinal motility since agonists on the $5-\mathrm{HT}_{4}$ receptor are accepted potent prokinetics [30]. Interestingly, high affinity receptor binding of the extracts of chelidonii herba on the muscarinic $\mathrm{M}_{3}$ receptor was proven. This receptor is involved in cholinergic stimulation of smooth muscle cells [29].

Effects of STW 5 or its constituents on motility have rarely been characterized. In guinea pig gastric fundus and corpus smooth muscle strips, STW 5 potently reduced basal tone whereas the tone of antral smooth muscle strips remained unchanged. In contrast, phasic activity and amplitude of antral contractions were increased [31]. This may indicate that gastric adaptive relaxation of fundus and corpus is enhanced and antral activity is increased, both desired effects in patients with dyspepsia and impaired gastric emptying. The individual constituents showed different effects on the observed parameters, suggesting that the combination of the different extracts in STW 5 is essential for the balanced additive effect [31]. In agreement with our findings, the individual extracts caused different effects which resulted in an additive effect for the herbal preparation STW 5.

Comparable tonic and spasmolytic effects were reported earlier for guinea pig small intestine. Cholinergicmediated contractions are decreased by STW 5 whereas the extract of I. amara alone has a tonic effect on smooth muscle [32]. In addition, I. amara extract stimulates phasic basal activity of small intestine, similarly to the stimulatory effect on antral phasic activity observed with $I$. amara extract. Moreover quantitative comparison indicates that the spasmolytic potency of STW $5(10 \mathrm{ml} / \mathrm{l})$ is higher than that of papaverin $(10 \mathrm{mg} / \mathrm{l})$ [32]. Interestingly, STW 5 has a tonic action under basal conditions and a relaxant action in precontracted smooth muscle [32]. This multiple mode of action might be attributed to the different individual constituents and their individual effects on motility patterns [33] and its balanced mode of action might be the key to the proven therapeutic benefit of STW 5 in the functional diseases in which it is used.

Further investigation on the main constituents of the individual herbal extracts (e.g. silibinin, chelidonin, protopin, glycyrrhicinic acid) showed individual effects on smooth muscle preparations, but none of these individual substances exerted the effects of the STW 5 herbal preparation [33].

Besides its effects on motility parameters, STW 5 also reduced neuronal activity following small intestinal stimulation by pharmacological (5-HT, bradykinin) or mechanical intraluminal stimuli, indicating that the sensitivity of the small intestine was reduced [34]. The effects on sensitivity include chemo- and mechano-sensitive afferent neurons and the chemo-sensitive neurons include vagal afferent neurons (5-HT sensitive) and spinal afferent neurons (bradykinin-sensitive) [34]. The effects on mechano-sensitive neurons can be observed following low and high pressure on small intestinal mucosa [34]. Additionally, there are reports on anti-ulcerative and acid suppressing actions [35], suppression of Helicobacter pylori growth [36] and antioxidative properties [33, 37]. Especially the antioxidative effects might partially influence motility parameters since some neurotransmitters in the enteric nervous system (e.g. nitric oxide) are influenced by the presence of free radicals [38].

In summary this investigation shows that herbal extracts modulate RMP as well as slow wave amplitude and rhythmicity of mouse small intestinal circular smooth muscle which are the electrophysiological basis of smooth muscle contractility and motility phenomena of the intestine. The effects of the individual herbal extracts used in the herbal preparation STW 5 add up to a total effect and the addition of individual effects might be the reason why STW 5 is helpful in relieving functional gastrointestinal symptoms in disorders of various origins and presently unknown pathophysiologies.

\section{Acknowledgements}

This study was supported by Steigerwald Arzneimittelwerk $\mathrm{GmbH}$, Darmstadt, Germany. M.S. was supported by a scientific grant given by the University of Munich (Förderprogramm für Forschung und Lehre - FöFoLe 357). 


\section{References}

1 Madisch A, Melderis H, Mayr G, Sassin I, Hotz $\mathrm{J}$ : A plant extract and its modified preparation in functional dyspepsia. Results of a doubleblind placebo controlled comparative study. Z Gastroenterol 2001;39:511-517.

2 Saller R, Reichling J: Drugs with Iberis amara as a modern phytotherapy to treat chronic functional disorders of the gastrointestinal tract. Forsch Komplementärmed Klass Naturheilkd 2002;9(suppl 1):V-VI.

3 Rösch W, Vinson B, Sassin I: A randomised clinical trial comparing the efficacy of a herbal preparation STW 5 with the prokinetic drug cisapride in patients with dysmotility type of functional dyspepsia. Z Gastroenterol 2002; 40(6):401-408

4 Mac LN, Hubner-Steiner U: Treatment of drug-induced gastrointestinal disorders. Double-blind study of the effectiveness of Iberogast compared to placebo. Fortschr Med 1987;105: 239-242.

5 Gundermann KJ, Godehardt E, Ulbrich M: Efficacy of a herbal preparation in patients with functional dyspepsia: A meta-analysis of double-blind, randomized, clinical trials. Adv Ther 2003;20:43-49.

6 Reichling J, Saller R: Iberis amara L. (bitter candytuft) - profile of a medicinal plant. Forsch Komplementärmed Klass Naturheilkd 2002;9(suppl 1):21-33.

7 Huizinga JD, Thuneberg L, Kluppel M, Malysz J, Mikkelsen HB, Bernstein A: W/kit gene required for interstitial cells of Cajal and for intestinal pacemaker activity. Nature 1995; 373:347-349.

8 Sanders KM: A case for interstitial cells of Cajal as pacemakers and mediators of neurotransmission in the gastrointestinal tract. Gastroenterology 1996;111:492-515.

9 Hara Y, Kubota M, Szurszewski JH: Electrophysiology of smooth muscle of the small intestine of some mammals. J Physiol 1986;372: 501-520.

10 Sancholuz AG, Croley TE, Glover JR, Macagno EO, Christensen J: Distributions of spike bursts in cat duodenum. Am J Physiol 1975; 229:925-929.

11 Lammers W, Slack JR: Slow waves, spike patches, and 'propagating contractions'. Gastroenterology 2001;121:742-743.

12 Lammers WJ, Stephen B, Slack JR: Similarities and differences in the propagation of slow waves and peristaltic waves. Am J Physiol Gastrointest Liver Physiol 2002;283:G778-G786.

13 Lee JC, Thuneberg L, Berezin I, Huizinga JD Generation of slow waves in membrane potential is an intrinsic property of interstitial cells of Cajal. Am J Physiol 1999;277:G409-G423.
14 Stevens RJ, Publicover NG, Smith TK: Propagation and neural regulation of calcium waves in longitudinal and circular muscle layers of guinea pig small intestine. Gastroenterology 2000;118:892-904.

15 Daniel EE, Wang YF: Gap junctions in intestinal smooth muscle and interstitial cells of $\mathrm{Ca}$ jal. Microsc Res Tech 1999;47:309-320.

16 Schultz T, Daniel V, Daniel EE: Does ICC pacing require functional gap junctions between ICC and smooth muscle in mouse intestine? Neurogastroenterol Motil 2003;15:129-138.

17 Jimenez M, Borderies JR, Vergara P, Wang Y, Daniel EE: Slow waves in circular muscle of porcine ileum: Structural and electrophysiological studies. Am J Physiol 1999;276:G393G406.

18 Daniel EE, Thomas J, Ramnarain M, Bowes TJ, Jury J: Do gap junctions couple interstitial cells of Cajal pacing and neurotransmission to gastrointestinal smooth muscle? Neurogastroenterol Motil 2001;13:297-307.

19 Kim TW, Koh SD, Ördög T, Ward SM, Sanders KM: Muscarinic regulation of pacemaker frequency in murine gastric interstitial cells of Cajal. J Physiol 2003;546:415-425.

20 Sanders KM, Koh SD, Ördög T, Ward SM: Ionic conductances involved in generation and propagation of electrical slow waves in phasic gastrointestinal muscles. Neurogastroenterol Motil 2004;16:100-105.

21 Sibaev A, Franck H, Vanderwinden JM, Allescher HD, Storr M: Structural differences in the enteric neural network in murine colon: Impact on electrophysiology. Am J Physiol Gastrointest Liver Physiol 2003;285:G1325G1334.

22 Storr M, Sibaev A, Marsicano G, Lutz B, Schusdziarra V, Timmermans JP, Allescher HD: Cannabinoid receptor type 1 modulates excitatory and inhibitory neurotransmission in mouse colon. Am J Physiol Gastrointest Liver Physiol 2004;286:G110-G117.

23 Der-Silaphet T, Malysz J, Hagel S, Larry AA, Huizinga JD: Interstitial cells of Cajal direct normal propulsive contractile activity in the mouse small intestine. Gastroenterology 1998; 114:724-736.

24 Huizinga JD, Farraway L, Den Hertog A: Effect of voltage and cyclic AMP on frequency of slow-wave-type action potentials in canine colon smooth muscle. J Physiol 1991;442:31-45.

25 Ward SM, Burns AJ, Torihashi S, Sanders KM: Mutation of the proto-oncogene c-kit blocks development of interstitial cells and electrical rhythmicity in murine intestine. J Physiol 1994;480:91-97.

26 Huizinga JD, Farraway L, Den Hertog A: Generation of slow-wave-type action potentials in canine colon smooth muscle involves a non-Ltype $\mathrm{Ca}^{2+}$ conductance. J Physiol 1991;442:1529.
27 Liu LW, Thuneberg L, Huizinga JD: Cyclopiazonic acid, inhibiting the endoplasmic reticulum calcium pump, reduces the canine colonic pacemaker frequency. J Pharmacol Exp Ther 1995;275:1058-1068.

28 Malysz J, Donnelly G, Huizinga JD: Regulation of slow wave frequency by $\mathrm{IP}_{3}$-sensitive calcium release in the murine small intestine. Am J Physiol Gastrointest Liver Physiol 2001; 280:G439-G448.

29 Simmen U, Kelber O, Jäggi R, Büter B, Okpanyi SN, Weiser D: Relevance of the herbal combination of STW 5 for its binding affinity to the muscarinic $\mathrm{M}_{3}$ receptor. Naunyn Schmiedeberg's Arch Pharmacol 2003;367 (suppl 1):R22.

30 Cucchiara S: Cisapride therapy for gastrointestinal disease. J Pediatr Gastroenterol 1996;22: 259-269.

31 Hohenester B, Schemann M: The phytopharmacon iberogast modulates gastric tone and contractility. Neurogastroenterol Mot 2003; 15 : 578.

32 Okpanyi SN, Mark M, Wahl M: Gastrointestinal motility modulation with iberogast. Acta Horticulturae 1993;332:227-235.

33 Heinle H, Pascht U, Kelber O, Okpanyi SN, Weiser D: Effekte der Einzelkomponenten von Iberogast auf die Spontanaktivität im Meerschweinchen-Ileum in vitro; in Kongressband der Mitteldeutschen Gesellschaft für Gastroenterologie. Tübingen, Mitteldeutsche Gesellschaft für Gastroenterologie, 2003.

34 Liu CY, Kelber O, Mueller mH, Glatzle J, Enck P, Grundy D, Kreis ME: The herbal preparation STW 5 (Iberogast/TM) desensitizes intestinal afferent responses to mechanical and chemical stimuli in the rat (abstract). Gastroenterology 2003;126(suppl 1).

35 Khayyal MT, el Ghazaly MA, Kenawy SA Seif-el-Nasr M, Mahran LG, Kafafi YA, Okpanyi SN: Antiulcerogenic effect of some gastrointestinally acting plant extracts and their combination. Arzneimittelforschung 2001;51: 545-553.

36 Beil W, Birkholz C, Sewing KF: Effects of flavonoids on parietal cell acid secretion, gastric mucosal prostaglandin production and Helicobacter pylori growth. Arzneimittelforschung 1995;45:697-700.

37 Schempp H, Toth A, Weiser D, Elstner EF Antioxidative properties of Iberis amara extracts in biochemical model reactions. Arzneimittelforschung 2003;53:568-577.

38 del Rio LA, Corpas FJ, Sandalio LM, Palma JM, Barroso JB: Plant peroxisomes, reactive oxygen metabolism and nitric oxide. IUBMB Life 2003;55:71-81. 